
8 Research Square
Preprints are preliminary reports that have not undergone peer review.
They should not be considered conclusive, used to inform clinical practice, or referenced by the media as validated information.

\title{
Interlocking Directorate and Firm Performance: Distance, Size, and Endogeneity
}

\author{
Tullio Buccellato \\ Confindustria Economic Research Department \\ Riccardo Busin \\ Ca' Foscari University of Venice \\ Roberto Casarin ( $\nabla$ r.casarin@unive.it ) \\ Ca' Foscari University of Venice \\ Giancarlo Corò \\ Ca' Foscari University of Venice
}

\section{Research Article}

Keywords: firm performance, interlocking directorates, network formation, network econometrics.

Posted Date: February 18th, 2022

DOI: https://doi.org/10.21203/rs.3.rs-1349267/v1

License: @ (i) This work is licensed under a Creative Commons Attribution 4.0 International License. Read Full License 


\section{Abstract}

Background

This paper contributes to the literature on interlocking directorates (ID) by providing a new solution to the two inference issues arising in the joint analysis of interlocks and firm performance which are the endogenous nature of ID and sample selection bias due to the exclusion of isolated firms.

\section{Method}

Some key determinants of ID network formation are identified and used to control for endogeneity. The instruments for eigen-centrality and clustering coefficient are based on the features of the degree-neighbors of a firm. The estimated the Mills ratio is used as a regressor in the second stage of the twostage least square to deal with the sample selection bias. We analyze the impact of the positioning in the network on firms' performance and inspect how the impact varies across firms of different sizes drawing on information relating to 37,324 firms in the interlocking network which, to our knowledge, is the widest dataset ever used in approaching the study of ID

$\underline{\text { Results }}$

Our results, made robust for endogeneity and sample selection bias, suggest that eigenvector centrality and the clustering coefficient have a positive and significant impact on all the performance measures and that this effect is more pronounced for small firms.

\section{$\underline{\text { Conclusion }}$}

A new inference framework is provided to assess the impact of the positioning of the firm in the network on its performance while controlling for endogeneity in the network structure. An application of the proposed framework to an original ID dataset provides new empirical results on the firm positing within the ID network.

\section{Introduction}

Directors sitting on the same board share an enhanced level of trust, whereas directors sitting on multiple boards allow spillover effects to go beyond the walls of the individual firm and spread out over a wider network. Following the Resource Dependence Theory, Interlocking Directorates (ID) widens access to resources by enhancing awareness of updates in technology, finding appropriate resources to finance sizeable projects, assessing business risks and opportunities, adopting cooperative strategies to penetrate new markets, and sharing good practices and useful information to organize production efficiently. All this positively affects the performance of the firm. On the other hand, agency theory investigates the possibility of managers forming ties and connections for opportunistic reasons. This behavior hence distracts from the optimal business administration of the firm and hinders its performance. The rigid division between the opposite schools of thoughts may hide grey zones where the effect of interlocking on the performance of the firm could vary according to different characteristics of the firm itself or, alternatively, to the position that it covers in the ID networks (Zona, Luis and Withers, 2018). See Caiazza and Simoni 2015, for an up-to-date review of the empirical studies on the causes and effects of ID and Caiazza and Simoni 2019 for a review from a historical perspective. This paper aims at filling some relevant gaps in the econometrics of ID networks.

An original solution to some econometric issues arising in the analysis of the relationship between ID network and firm performance is suggested. This analysis usually involves centrality measures such as degree, eigenvector centrality and clustering coefficient, which are metrics directly derived from the ID network and which capture different features of how a firm participates in the network itself. As regards the performance indicators, these are based on variables contained in annual balance sheets and pertain to four aspects, namely, profitability, debt sustainability, financial independence, and productivity. This analysis requires rigorous econometric methods to deal with two main sources of endogeneity. Firstly, issues could arise relating to the possible selection of firms which become part of the ID network. The probability of this occurrence could, in itself, be correlated with the performance of the firm (Uzzi 1999; Rossoni, Aranha and Mendes-da-Silva 2017). Then, centrality measures may be endogenous with respect to performance indicators since ID network and performances may be simultaneously determined (Abdelbadia and Salama 2019; Buscle 2008). Our analysis is designed to be robust with respect to the two sources of endogeneity mentioned above. To this purpose we combine a two-stage procedure for simultaneity-bias correction using a Heckman procedure for correcting sample selection bias which requires the identification of the determinants of ID network formation as described in Wooldridge 2010.The second contribution of this paper is to identify a number of key variables showing their effectiveness when employed in correcting estimation bias. Taking stock of previous studies, this paper analyses the affiliation network of 37,324 interlocked firms in Italy. We begin by exploring the nature of the network and discern that it is not randomly generated. The size, the geographic position, and the sector of the firm are key factors affecting the intensity and shape of the network and, hence, important controls to be considered when analyzing the relationship of ID and performance. Our empirical results indicate that estimation bias heavily affects ID estimates as well as the performance relationship when a standard regression approach is applied. Moreover, the magnitude and sign of the bias change following the firm size.

Finally, the present study inspects how the impact of the interlock on the performances varies across firms of different sizes. Several previous studies have addressed the open question of how interlocking might affect firm performance (see Pfeffer 1972; Roomens, Cuyvers and Deloof 2007; Wincent, Anokhin and Örtqvist 2010; Zona, Bellinzier and Grassi 2013; Croci and Grassi 2014; Kamuriwo 2016). There is consensus on some recurring results such as, for instance, that centrality measures such as degree are often found to have a negative impact on profitability or on the value of firms listed in public stock exchanges. A common trait of many of these studies is that they focus on large firms, often limiting the analysis to firms that are publicly listed. Such limitation has made it difficult to have results which may be generalized to firms of smaller dimension, although in the literature have been flagged up various channels through which ID could impact the performance of small firms, i.e. expanding the circle of individuals taking decisions within the firm (Brunninge, Nordqvist and Wiklund 2007), representing an alternative source of accumulating external knowledge (Weemaes et al. 2020), or interdependence as a way of sharing trust

Page 2/21 
and solidarity across firms (Huse 1994). This paper applies inference procedure robust for ID network endogeneity and provides evidence that eigenvector centrality and clustering coefficient have a positive impact on firm performance, especially for firms of smaller size.

The study is organized as follows. Section 2 provides a review of the key findings in the literature on ID and summarizes them through some key research questions. Section 3 introduces the data and the summary statistics. Section 4 illustrates the econometric model. Section 5 discusses the involved regression results. Finally, Section 6 presents our conclusions.

\section{Literature Review}

Many studies have focused on the role that interlocking directorates (ID) could play in affecting the performance of the firm. Most of the studies have focused on datasets constituted by samples of large firms, often selected because listed on international stock markets. If these studies have had the merit of analyzing quantitatively the effects of interlocking, the fact of being based on limited samples of companies did not allow to generalize the results to wider firm communities, especially small-sized ones. In this section, we summarize some of the results paying attention to the data and method used to obtain them.

Boyd 1990, based on a sample of 147 corporate firms listed on the stock exchange, conducted an analysis using the ordinary least square and the maximum likelihood estimator to find that firms with higher number of ties through having their directors on multiple boards exhibit better performances in terms of faster increase in sales and higher returns on capital. The underlying reason for the performance improvement is that more connected firms are more shielded from the negative effects of uncertainty.

Phan et al 2003 study the effects of interlocking for a sample of 191 listed companies in Singapore collecting information from several sources annual balance sheets and other reports, articles in the news and magazines, documents issued by the stock exchange and phone interviews. The results confirm the idea that interlocking is a way to gather information on the environment where the firm operate, alleviating risks connected to uncertainty (the authors find that their results are in line with Pfeffer e Salancik 1978).

Fich and Shivdasani 2004 conduct a panel data analysis on 508 firms from the Forbes 500 of 1992 . The firms are selected based on being the larger in terms of sales, market capitalization and profits over the period 1989-1995. The fixed effect regressions show that firms with "buzy" directors, that is active on multiple boards, suffer worse performances in terms of market-to-book ratio and profitability.

Non and Frances 2007 exploit a panel of 101 large firms from the Netherlands over the decade 1994-2004 using information of the annual balance sheets as stored in the database REACH. The study confirms the negative effect of "business" of the manager, which are often part of cohesive groups of managers with multiple official assignments and meet regularly with each other's. The results also support the idea that more cohesion slows down firms in taking decisions as they often seek unanimity, and that this might also negatively affect the formation of critical and independent thought across boards of directors (Janis, 1982, e Mullen et al., 1994).

Roomens, Cuyvers and Deloof 2007 study a dataset of 286 companies connected to a holding listed company and 2,136 independent companies in Belgium; with this dataset the authors can control for both types of connections within and outside the group types of connections. The results suggest that firms within the group do not suffer issues of business of their manager and that the interlocking does not negatively affect the firm performance (nor positively).

Koka and Prescott 2008 conduct an analysis on 422 firms forming 766 alliances across 48 countries but just with a net prevalence of firms in the metallurgic sector (166 firms). The focus of the study is on strategic alliances and the different role that firms can play within the ID network, that is as firms occupying prominent positions or just entrepreneurial positions. The factor affecting performance is indeed the role and not the degree of connectivity, firms in weaker positions tend to perform worse with respect to those occupying strategic posts. For exposition purposes, we summarize the studies presented above through a list of relevant research questions.

RQ 1: Is the ID endogenous? If the endogeneity is not properly treated, can it jeopardize the validity of the ID and performance analysis?

RQ 2: Is centrality in the ID network associated with positive effects on the performances?

RQ 3: Are there valid instruments to correct for ID endogeneity?

Among the few studies analyzing the impact of being part of a network for Small and Medium Firms (SMEs) is the paper by Wincent, Anokhin and Örtqvist 2010. The dataset is constructed to encompass 53 strategic networks of SMEs: such groups are formed on a voluntary basis by firms with the clear objective of enhancing profitability, among firms relatively geographically close; the network of firms is identified in Sweden through interviews and qualitative research of the authors. The key purpose of the study is to assess the effects on of the diversity in background and human capital within the board of the firm: diversity appear to have a clearer effect on incremental research, whereas the level of instruction tends to affect more radical innovation. A relatively negative effect on innovation is instead played by the frequency of meetings of board members. Mazzola, Perrone and Kamuriwo 2016 argue that the additional benefit in terms of innovation stems from the presence of prominent directors from prominent firms in the interlocking letting trickle down useful information to other firms in the network; being prominent firms in the network also affects positively new product development.

Santos, Da Silveira and Barros 2012 analyze an unbalanced panel of around 320 firms listed on the Brazilian stock exchange (BOVESPA) for three years to assess the impact of interlocking on performance. This study is one of the most rigorous with respect to the robustness of the results, obtained through the use of a wide set of regression models, ranging from random effects, fixed effects to two-stage least squares and the general method of moments. The main result is again that managers sitting on multiple boards tend to be associated with lower book values of the firms.

Page $3 / 21$ 
Larcker, So and Wang 2014 use information from the Corporate Board Member Magazine Director Database on 115,411 and construct a panel of 6,600 firms and 52,000 directors over the period 2000-2007. The sample is constituted by all the listed companies on stock exchanges such as NYSE, NASDAQ and AMEX, in addition to very large companies with sales exceeding $\$ 1$ billion. The results tend to find a positive relationship between centrality in the network of the firm and future return on assets, especially for younger firms. The positive effect goes in favor of the hypothesis that connectedness implies enhanced access to resources such as information and capital.

Croci and Grassi (2014), based on OLS analysis implemented on data relating 282 firms, find a positive effect of betweenness on firm value and a negative effect of centrality measures such as degree and eigen centrality with respect to the value of the firm. As regards the effect on return on assets they find a negative result, which this time is found also for betweenness; the clustering coefficient is never significant.

Always referring to the case of Italian firms, Bellinzier and Grassi (2013) study the evolution of the interlocking network between 1998 and 2011 of listed companies on Milan stock exchange and find out that it has a persistent small world structure. The network is cohesive thanks to few directors (big linkers) that tend to sit in many boards. Persistence in the network is mainly due to the reduced number of families controlling the firms and to cross-shareholdings of companies. The analysis refers to publicly listed company and the companies occupying central positions in the network are those representing the pillars of Italian capitalism: Pirelli SpA, Mediobanca, RCS, Italcementi.

Zona, Luis and Withers (2018) address the analysis of performance referring to a resource-based and agency cost theory. According to the former conceptual framework interlocking would enhance performance as it would relax the internal constraints of the single firm allowing for access to a greater amount of resources, whereas according to the to the agency cost theory ID would exacerbate the problems relating to managerial opportunism with detrimental effects on performance. Based on GMM estimates on data relating 145 firms over the period 2001-2006, the authors conclude that the outcome in terms of performance depends upon the dyadic relationship between the focal and the interlocked firms: putting together the perspectives of agency and resource dependence shows that executives may use interfirm tactics for different purposes and that this might depend on the characteristics of the firm and of the interfirm relations. More in particular successful interlocking is those between firms with limited resources that are coopted in the network of richer and more powerful firms. As regards the implied results connected to the agency cost-based theory, the interlocking might be more problematic when the firm is more connected with fragmented ownership, that is with manager that are more independent from providers and shareholders.

Brauno, Briones and Islasa 2019 analyse the interlocking directorate of 252 firms, in practice nearly all the firms listed on the Chilean stock market, 1198 directors sitting on 1873 places across the boards of these firms. The key result of the paper is that firms interlocked with banks have superior market evaluations and tend to last longer on the market

Summarizing, several studies have been conducted worldwide to assess the effect of interlocking directorates on the performance of the firm. The most of articles have focused on large companies listed on public stock exchanges. The studies in general tend to suggest that the degree has a negative impact on the profitability and value of the firm, and this could result for instance from the business of the managers, which might lose focus from fostering the fundamentals of the firm. However, results might change when analyzing the relationship from different angles (e.g., agent based. Vs agency cost theory) or referring to specific layers of the network (e.g., prominent vs entrepreneurial firms). The studies have usually limited samples cutting out smaller firms. For the sake of clarity, we summarize the studies discussed above through two relevant questions related to the size of the firms.

RQ 4: Is the magnitude of the impact of ID on performances larger for smaller firms?

RQ 5: When ID endogeneity is not treated properly in the econometric analysis, is the bias in the ID and performance relationship larger for smaller firms?

\section{Data And Interlocking Network Description}

We use information on 94,018 limited companies with a turnover of at least 1,000,000 euros. This threshold is selected after consulting with the association of Italian accountants, who consider this size of turnover a milestone for individual firms to avoid endemic instability as well as the risk of default. We exploit information on the composition of the board of directors, as reported by each firm, to draw the map of ties between firms which takes the shape of an undirected network. We have access to data on the affiliation network in which the actors are the company directors and the groups are the boards to which they belong. The network is bipartite as it can be represented both considering each company or, alternatively, the members of the boards as nodes.

We refer to the first representation of the network, for which each pair of firms is connected through a stronger tie and where the number of common directors is higher. 56,694 firms are islands, that is, they do not share any of their board members with other firms. The remaining 37,324 firms are part of the interlocking network. Figure 1 provides a graphical representation of the network excluding the islands.

There are 7645 components in the network. The giant component has 15,357 observations and most of the other components are couples ( $39.2 \%$ ) or triangles (18.2\%). Interlocking is a relatively frequent phenomenon across Italian firms as just less than $40 \%$ of them exhibit at least one tie with at least one firm via sharing at least one director on their respective boards. The average number of ties for each firm is 1.5 for the whole dataset, it increases to 3.8 when islands are excluded, and the maximum degree is 65 (Table 1 ).

Table 1 - Descriptive statistics of the network 


\begin{tabular}{lllllll} 
& Minimum & Maximum & Mean & Skewness & St.Dev & Observation \\
\hline Complete network & 0 & 65 & 1,5 & 5,2 & 3,6 & 94018 \\
\hline Network without islands & 1 & 65 & 3,8 & 3,8 & 4,9 & 37324 \\
\hline & & & & & $\%$ interlocked & $39,7 \%$
\end{tabular}

Source: authors' calculations based on Aida Bureau Van Dijk

Figure 2 shows the grouping of firms in the giant component according to their sector. A simple inspection of the graphs highlights the presence of communities and nodes of different levels of centrality.

Nevertheless, drawing any conclusions may be arduous as the network has many nodes and edges. Network statistics reveal the complex structure of the giant component with an average degree of 6.05 , an average clustering coefficient of $0.55,108$ communities, and a density of 0.0003 given by $91.5 \%$ of ties between macro-sectors and by the $8.5 \%$ of ties within macro-sectors.

To provide a better graphical representation we focus on the firms that exhibit a higher level of eigenvector centrality and isolate seven subcomponents of the network (Figure 3). As can be noticed, there seems to be a pattern across sectors. The green dots represent all the firms operating in ICT, whereas the red dots operate in retail-sales. Further, the dark blue dots indicate in the health and medical sector and, finally, the light blue dots refer to the manufacturing of machinery. The sectoral pattern in the distribution of ties suggests that the formation of the network may not be random.

A closer look at the distribution of firms according to their degree as reported in Figure 4, shows that the formation of the network follows a power law of exponent 2 where the number of firms decreases monotonically across the logarithmic binning of the degree. This result confirms the non-random nature in the formation of the network.

The spatial pattern that characterizes the structure of the network is confirmed through the analysis of the distribution of the edges according to distance thresholds expressed in kilometers (Figure 5). Nearly $40 \%$ of the connections in the network are established below a distance threshold of 10 kilometers and, of these, more than a half happens within the same postal code. The structure of the network weakens rapidly on higher distance arrays, but, over $100 \mathrm{~km}$ it tends to remain more persistent and to lose the monotonicity in the decreasing pattern.

The extent to which firms are interconnected via their board members varies across different sectors. Table 2 displays the percentage of firms that are interlocked by macro-sector. This statistic varies substantially in the sample and ranges between the $80.2 \%$ of the energy sector and the $30.5 \%$ of construction activities. The subsequent two sectors after the energy sector exhibiting a higher degree of interlockings are financial and insurance activities, and real estate activities. Table 2 also reports the average of three different measures of centrality within the network. These are the degree, simply calculated as the number of firms with which one given node (or firm) is connected; the eigenvector centrality, which is a score proportional to the sum of the degrees of the neighbors; and, the clustering coefficient, which is a measure of transitivity and cohesion regarding the way firms tend to interconnect with each other[1]. The highest average degree is found for those activities relating to the provision of electrical energy and gas, financial and insurance activities, and ICT (all with average degree above 5). However, when considering eigen centrality, the ICT sector results are, on average, the most central. These sectors also exhibit a relatively high level of cohesion as captured by the clustering coefficient. The firms that are part of these subnetworks tend to be highly interconnected among themselves, following the model "the friend of my friend is also my friend"[2]. The clustering coefficient is on average relatively high in the construction sector

Table 2- The degree, eigen centrality and clustering coefficient by macro-sector 


\begin{tabular}{|c|c|c|c|c|c|}
\hline Macrosector & $\begin{array}{l}\% \text { of firms } \\
\text { interlocked }\end{array}$ & $\begin{array}{l}\text { Average } \\
\text { degree }\end{array}$ & $\begin{array}{l}\text { Average eigenvector } \\
\text { centrality }\end{array}$ & $\begin{array}{l}\text { Average clustering } \\
\text { coef. }\end{array}$ & Observation \\
\hline Agriculture, silviculture and fishing & $53,4 \%$ & 2,02 & 0,002 & 0,20 & 2194 \\
\hline Mining & $55,3 \%$ & 1,45 & 0,001 & 0,23 & 266 \\
\hline Manufacturing & $34,4 \%$ & 1,06 & 0,001 & 0,15 & 32701 \\
\hline Electric, gas and steam power & $80,2 \%$ & 4,99 & 0,006 & 0,49 & 789 \\
\hline Water, sewerage, and waste & $47,9 \%$ & 1,79 & 0,001 & 0,19 & 1128 \\
\hline Constructions & $30,5 \%$ & 1,15 & 0,002 & 0,13 & 6745 \\
\hline $\begin{array}{l}\text { Retail and wholesale commerce, repairing of auto } \\
\text { and motorcycles }\end{array}$ & $33,2 \%$ & 1,17 & 0,001 & 0,14 & 21490 \\
\hline Transport and storage & $42,9 \%$ & 1,66 & 0,001 & 0,20 & 5460 \\
\hline Hotel and restaurants & $43,4 \%$ & 1,44 & 0,001 & 0,21 & 2632 \\
\hline Information and communication & $51,6 \%$ & 2,80 & 0,015 & 0,25 & 3482 \\
\hline Financial and insurance activitites & $69,1 \%$ & 4,19 & 0,004 & 0,27 & 1617 \\
\hline Real estate activities & $69,1 \%$ & 2,99 & 0,005 & 0,38 & 2247 \\
\hline Professional, scientific and technical activities & $53,4 \%$ & 2,46 & 0,003 & 0,24 & 4818 \\
\hline $\begin{array}{l}\text { Rental, travel agencies and other services of support } \\
\text { for the firms }\end{array}$ & $45,7 \%$ & 1,76 & 0,001 & 0,20 & 3635 \\
\hline Instruction & $46,3 \%$ & 1,59 & 0,001 & 0,16 & 480 \\
\hline Health and social assistance & $46,7 \%$ & 2,22 & 0,005 & 0,21 & 3077 \\
\hline Art, sport and entartainment & $50,3 \%$ & 2,35 & 0,002 & 0,21 & 753 \\
\hline \multirow[t]{2}{*}{ Other services } & $34,9 \%$ & 1,34 & 0,001011 & 0,13 & 504 \\
\hline & & & & Tot. Obs. & 94018 \\
\hline
\end{tabular}

Source: authors' calculations based on Aida Bureau Van Dijk.

We then focus on manufacturing activities, which on average display a relatively low level of interlocking (34.4\%) even though, there is a relatively high variation across subsectors. The two oligopolistic sectors of tobacco with just 8 firms in the sample, and coke and petroleum have a higher frequency of interlocking (87.5\% and $70.6 \%$ respectively). Overall, manufacturing exhibits the lowest degree (1.1), but hides a high heterogeneity across the sub-sectors considered individually. The sector of hydrocarbon processing is the one that also exhibits one of the highest degrees (5.033). The next sector with a relatively high average degree is the one relating to metallurgic economic activities (4.045), which is also the sector characterized by the highest clustering coefficient. When it comes to eigenvector centrality, the machinery sector is associated the highest average score $(0.005)$.

Table 3 - The degree, eigen centrality and clustering coefficient by manufacturing sector 


\begin{tabular}{|c|c|c|c|c|c|}
\hline Sector & $\begin{array}{l}\% \text { of firms } \\
\text { interlocked }\end{array}$ & $\begin{array}{l}\text { Average } \\
\text { degree }\end{array}$ & $\begin{array}{l}\text { Average eigenvector } \\
\text { centrality }\end{array}$ & $\begin{array}{l}\text { Average clustering } \\
\text { coef. }\end{array}$ & Observation \\
\hline Food & $42,2 \%$ & 1,38 & 0,001 & 0,17 & 2637 \\
\hline Beverage & $51,1 \%$ & 1,85 & 0,001 & 0,20 & 511 \\
\hline Tobacco & $87,5 \%$ & 3,38 & 0,003 & 0,13 & 8 \\
\hline Textile & $35,7 \%$ & 0,95 & 0,001 & 0,14 & 1287 \\
\hline Apparel and leather & $26,7 \%$ & 0,95 & 0,001 & 0,12 & 1819 \\
\hline Wood products (excl. Furniture) & $21,1 \%$ & 0,51 & 0,000 & 0,08 & 755 \\
\hline Paper & $37,0 \%$ & 1,10 & 0,001 & 0,17 & 735 \\
\hline Printing & $26,2 \%$ & 0,85 & 0,001 & 0,11 & 694 \\
\hline Coke and petroleum & $70,6 \%$ & 3,55 & 0,002 & 0,33 & 85 \\
\hline Chemical & $46,7 \%$ & 1,67 & 0,001 & 0,23 & 1255 \\
\hline Pharmaceutical & $57,8 \%$ & 1,92 & 0,001 & 0,26 & 268 \\
\hline Rubber and plastic & $37,1 \%$ & 1,04 & 0,001 & 0,17 & 2063 \\
\hline Non metal minerals & $40,3 \%$ & 1,16 & 0,001 & 0,16 & 1259 \\
\hline Metallurgy & $47,6 \%$ & 1,93 & 0,001 & 0,27 & 846 \\
\hline $\begin{array}{l}\text { Metal products (excluding } \\
\text { machineries) }\end{array}$ & $24,9 \%$ & 0,66 & 0,000 & 0,10 & 6895 \\
\hline Electronic and precision equipment & $38,2 \%$ & 1,17 & 0,001 & 0,16 & 1056 \\
\hline Electric and domestic equipment & $38,3 \%$ & 0,99 & 0,000 & 0,17 & 1451 \\
\hline Machinery & $37,4 \%$ & 1,28 & 0,002 & 0,18 & 5210 \\
\hline Autovehicles & $43,9 \%$ & 1,40 & 0,001 & 0,21 & 545 \\
\hline Other transport & $36,8 \%$ & 1,23 & 0,001 & 0,17 & 302 \\
\hline Furniture & $24,7 \%$ & 0,65 & 0,000 & 0,11 & 1046 \\
\hline \multirow[t]{2}{*}{ Other } & $29,9 \%$ & 0,83 & 0,001 & 0,12 & 1974 \\
\hline & & & & Tot. Obs. & 32701 \\
\hline
\end{tabular}

Source: authors' calculations based on Aida Bureau Van Dijk.

Besides geography and sector membership, the third determinant for the formation of the network is the size of the firm. Larger firms are much more likely to be part of an ID network and, in fact, $70.3 \%$ of the firms of the sample have at least one connection with others. Participation in the ID network is inversely proportional to the size of the business. In our sample, just over one firm in two are interlocked among medium-sized firms. Small firms and micro firms are interlocked to a lesser degree (at $30 \%$ and $28.4 \%$ respectively). The same pattern is found for the centrality measures with degree, eigenvector centrality and clustering coefficient on average increasing with the size of the firm (Table 4).

Table 4 - The degree, eigen centrality and clustering coefficient by firm size

\begin{tabular}{llllll} 
Size & \% of firms interlocked & Average degree & Average eigenvector centrality & Average clustering coef. & Observation \\
\hline Micro (<10 employees) & $34,2 \%$ & 1,25 & 0,001 & 0,15 & 32104 \\
\hline Small (10-49 employees) & $35,3 \%$ & 1,21 & 0,002 & 0,15 & 43648 \\
\hline Medium (50-249 employees) & $56,4 \%$ & 2,41 & 0,004 & 0,27 & 14721 \\
\hline Large (>250 employees) & $74,5 \%$ & 4,08 & 0,005 & 0,37 & Tot. Obs \\
\hline & & & & 94018
\end{tabular}

Source: authors' calculations based on Aida Bureau Van Dijk

[1] See Appendix A.1 for further details and Newman 2010 for an extensive discussion of these measures of transitivity.

[2] Newman 2010, pp.198.

\section{The Econometric Method}


In this section we investigate how interlocking affects the performance of the firms. The endogeneity of the network and an econometric treatment of this issues is discussed with the introduction of new instrumental variables. The relationship with the geographical proximity and the firm size is considered in the other sections.

We propose a simple econometric model, which alternate as dependent variables indicators of performance relating profitability, sustainability, the capability of the firms to find financial resources autonomously, and a variable to measure the efficiency in the productive process. We use three indicators of network centrality - degree to which we and some control variables that are standard for models at the firm level. We construct a model that takes the following shape:

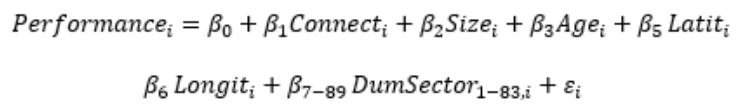

Where the dependent variable is alternatively: the return on equity (ROE) as the proxy for profitability, the ratio between the debt and the earnings before interest, taxes, depreciation, and amortization (DEBTEBITDA) as an indicator of sustainability, the index of financial independence obtained as the ratio between own capital and total assets and productivity measured through the natural logarithm of the ratio between value added and the number of employees.

are measures of centrality for the firm $\mathrm{i}$ in the network added gradually to the model to test their combined effect on performance: the degree and, alternatively, the eigenvector centrality or the clustering coefficient. These metrics offer different perspectives to evaluate how the connectedness of the firm with the interlocking network affects the performance of the firm itself. As briefly anticipated above, the degree, i.e. the number of edges pertaining to each individual node, is the simplest measure of centrality providing information on the number of firms with which each individual firm is connected. Eigenvector centrality is an additional metric considered that takes into account also the importance of the neighbors to which each individual firm is associated, i.e. assigning to each node a value proportional to the degree of its neighbors. The last network metric considered is the clustering coefficient, simply calculated as the ratio of the number of pairs of neighbors of a given node that are connected to the overall number of pairs of that given node; such metric is informative on the cohesion of the local network to which a given node belongs.

We consider four additional variables designed to control for firm fixed effects: is the natural logarithm of the number of employees in the firm; is the number of years since when the firm has been incorporated; and are the geographical latitude and longitude of the postal code where the firm is positioned; is a set of 83 dummy variables which take value one when the firm is classified with a certain economic activity (NACE two digit) and zero otherwise.

The model in Equation (1) can be estimated by GLS, nevertheless, the inference might suffer two order of problems: (i) the method do not consider the possibility that performance and centrality measures could be determined simultaneously; (ii) the fact of being part of the ID network can make the centrality measures endogenous in the selected sample.

To deal with endogeneity we follow the approach proposed in Abdelbadia and Salama (2019) of using the board size as an instrument and implementing a two stage least square (2SLS) regression model (See Buscle 2008 for a discussion on controlling endogeneity and on the use of 2SLS). On average the 94,018 firms in the dataset have 3.5 board members, the median of the distribution is 3 and the maximum number of board members is 37 . Board size could be a suitable instrument for the centrality measure of degree, however we need also a variable to instrument eigenvector centrality and the clustering coefficient. To do this we compute the board size obtained as the sum of all the directors in the boards of the degree-neighbors of each individual firm we label such variable eigen board size (see See Appendix A.2).

To deal with the second issue relating the possible sample selection bias we adopt the procedure suggested by Wooldridge 2010, ch. 19 , which consists in estimating preliminary the Mills ratio through the probit and then using the estimated ratio as a regressor in the second stage of the two stage least square.

Operatively, we adapt the model depicted in Equation 1 to account for the two possible sources of bias affecting our sample, by first estimating the Mills ratio through a probit regression and then proceeding to estimate a two stage least square regression, encompassing in the first stage the instruments of board size and local board size and in the second stage the Mills ratio and the instrumented variables for centrality measures.

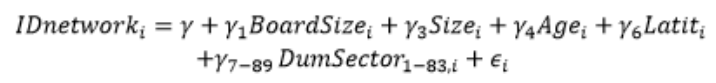

Where is a dummy variable, which takes value 1 if a firm is part of the network and 0 otherwise.

From Equation 3 we obtain the instrumented variables for degree and eigen centrality, i.e. the two variables for which board size and eigen bord size have been proved to be valid instruments.

We can hence construct a new model in which the estimated Mills ratio is included among the regressors and the network centrality metrics are replaced by their respective instrumented variables: 


\section{Empirical Results}

We start by estimating the model using the generalized least square method (GLS); the results are reported in Table 5. The block of 4 regressions 1-4 only includes degree as a measure of the centrality of the firm in the network. The results suggest that centrality may have a negative and significant effect on profitability and a positive effect on financial independence and productivity. Conversely, it does not exert a significant effect on the degree of indebtedness. In columns 5-8 we report results that also include eigenvector centrality among the regressors. Here, the sign and significance of the coefficients associated to degree remain the same, whereas eigen centrality exerts a positive and significant effect on profitability and a negative and significant effect on financial independence and productivity. The sign with respect to Debt/EBITDA is negative, even though it remains insignificant. Most strikingly, eigen centrality, that should possibly capture at best the "authority" of the firm in the network, appears to exert a negative effect on financial independence. As regards the clustering coefficient (columns 9-12 of Table 5), it appears to have a negative and significant effect on profitability, and a positive and significant impact on financial independence and productivity.

We study the effects of interlocking network endogeneity by comparing the previous results with the results obtained with the two-stage least square regression including the sample selection bias correction. First, we assess the validity of the instruments and check whether they are highly correlated with the centrality measures and poorly with the performance indicators. Table 6 displays the correlation of the board size and the eigen board size with respect to the four variables of performance used alternatively as dependent variables and where the network metrics are used as key regressors.

Table 5 - Generalized least square regression results

\begin{tabular}{|c|c|c|c|c|c|c|c|c|c|}
\hline & (1) & (2) & (3) & (4) & (5) & (6) & (7) & (8) & (9) \\
\hline VARIABLES & ROE & Debt/EBITDA & $\begin{array}{l}\text { Financial } \\
\text { independence }\end{array}$ & Productivity & ROE & Debt/EBITDA & $\begin{array}{l}\text { Financial } \\
\text { independence }\end{array}$ & Productivity & ROE \\
\hline \multirow[t]{2}{*}{ Degree } & -0.00460 & 0.000139 & $0.0220 * \star \star$ & $0.0282^{\star \star \star}$ & $-0.0531 * \star *$ & 0.00150 & $0.0367^{* \star \star}$ & $0.0375^{\star \star \star}$ & -0.00719 \\
\hline & $(0.00541)$ & $(0.00619)$ & $(0.00425)$ & $(0.00478)$ & $(0.00545)$ & $(0.00848)$ & $(0.00506)$ & $(0.00586)$ & $(0.00561)$ \\
\hline \multirow{2}{*}{$\begin{array}{l}\text { Eigen } \\
\text { centrality }\end{array}$} & & & & & $0.0718^{\star \star \star}$ & -0.00192 & $-0.0211 * \star \star \star$ & $-0.0129 * \star \star$ & \\
\hline & & & & & $(0.00546)$ & $(0.00341)$ & $(0.00327)$ & $(0.00386)$ & \\
\hline \multirow{2}{*}{$\begin{array}{l}\text { Clustering } \\
\text { coef. }\end{array}$} & & & & & & & & & 0.00920 ** \\
\hline & & & & & & & & & $(0.00454)$ \\
\hline \multirow[t]{2}{*}{ Size } & $0.0296^{\star \star \star}$ & 0.00992 & $-0.0177^{\star \star \star}$ & $0.262^{\star \star \star}$ & $0.0363^{\star \star \star}$ & 0.00973 & $-0.0198 * \star \star$ & 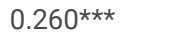 & $0.0292^{\star \star \star *}$ \\
\hline & $(0.00531)$ & $(0.00816)$ & $(0.00508)$ & $(0.00569)$ & $(0.00531)$ & $(0.00801)$ & $(0.00509)$ & $(0.00571)$ & $(0.00531)$ \\
\hline \multirow[t]{2}{*}{ Age } & $-0.117 \star \star \star$ & $0.0115^{\star}$ & $0.237^{\star \star \star *}$ & $0.0454^{\star \star \star}$ & $-0.118 * \star \star$ & $0.0115^{\star}$ & $0.237 \star \star \star *$ & $0.0455^{\star \star \star}$ & $-0.116 * \star \star$ \\
\hline & $(0.00670)$ & $(0.00645)$ & $(0.00520)$ & $(0.00620)$ & $(0.00668)$ & $(0.00645)$ & (0.00519) & $(0.00620)$ & $(0.00671)$ \\
\hline \multirow[t]{2}{*}{ Latitude } & $0.0411^{\star \star \star}$ & -0.00700 & $0.0564^{\star \star \star}$ & $0.0647 * \star \star$ & $0.0449 * \star \star$ & -0.00712 & $0.0553^{\star \star \star}$ & $0.0640 * \star \star$ & $0.0409 * \star *$ \\
\hline & $(0.00647)$ & $(0.00678)$ & $(0.00627)$ & $(0.00712)$ & $(0.00647)$ & $(0.00679)$ & $(0.00627)$ & (0.00713) & $(0.00647)$ \\
\hline \multirow[t]{2}{*}{ Longitude } & 0.00885 & -0.00835 & 0.00659 & $-0.0291 * \star \star$ & $0.0140 * \star$ & -0.00853 & 0.00496 & $-0.0302^{\star \star \star}$ & 0.00889 \\
\hline & $(0.00635)$ & $(0.00719)$ & $(0.00627)$ & $(0.00712)$ & $(0.00632)$ & $(0.00721)$ & $(0.00628)$ & $(0.00713)$ & $(0.00636)$ \\
\hline \multirow[t]{2}{*}{ Constant } & $-0.284^{\star \star \star}$ & $0.129 * \star \star$ & $-0.279 * \star \star$ & $0.291^{\star \star \star *}$ & $-0.263^{\star \star \star}$ & $0.128^{\star \star \star}$ & $-0.285^{\star \star \star}$ & $0.287^{\star \star \star *}$ & 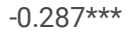 \\
\hline & $(0.0218)$ & $(0.0300)$ & $(0.0302)$ & $(0.0433)$ & $(0.0219)$ & $(0.0302)$ & $(0.0301)$ & $(0.0433)$ & $(0.0218)$ \\
\hline $\begin{array}{l}\text { Sector } \\
\text { controls }\end{array}$ & Yes & Yes & Yes & Yes & Yes & Yes & Yes & Yes & Yes \\
\hline Observations & 34,557 & 30,742 & 35,859 & 32,202 & 34,557 & 30,742 & 35,859 & 32,202 & 34,557 \\
\hline R-squared & 0.044 & 0.007 & 0.126 & 0.096 & 0.051 & 0.007 & 0.127 & 0.096 & 0.044 \\
\hline
\end{tabular}

Robust standard errors in parentheses. ${ }^{* *} p<0.01,{ }^{* *} p<0.05, * p<0.1$

Table 6 - Correlation to test the validity of the instruments 


\begin{tabular}{llllllll} 
& Degree & Eigen centrality & Clustering coef. & ROE & Dent/EBITDA & Financial Independence & Productivity \\
\hline Board size & 0.365 & 0.089 & 0.149 & $-0,084$ & 0,018 & 0,039 & 0,006 \\
\hline Eigen board size & 0.926 & 0.501 & 0.416 & $-0,019$ & 0,002 & 0,029 & 0,049
\end{tabular}

Source: authors' calculations based on Aida Bureau Van Dijk

Table 7 Heckman two-stage least square regression results
(1)
(2)
(3)

(4)

(5)

(6)

(7)

(8)

(9)

VARIABLES ROE

Debt/EBITDA

Financial

Productivity ROE

Debt/EBITDA

Financial independence

Productivity ROE independence

\begin{tabular}{|c|c|c|c|c|c|c|c|c|c|c|}
\hline \multirow[t]{2}{*}{ Degree } & $-0.176^{\star \star \star}$ & 0.0491 & -0.0391 ** & $-0.0954 * \star *$ & $-0.309 * * \star$ & $0.0866^{*}$ & $-0.0778 * \star \star$ & $-0.185^{\star \star \star}$ & $-0.0832^{\star \star \star}$ & 1 \\
\hline & $(0.0148)$ & $(0.0311)$ & $(0.0154)$ & $(0.0182)$ & $(0.0326)$ & $(0.0484)$ & $(0.0266)$ & $(0.0350)$ & $(0.00801)$ & 1 \\
\hline \multirow{2}{*}{$\begin{array}{l}\text { Eigen } \\
\text { centrality }\end{array}$} & & & & & $0.426^{\star \star \star}$ & $-0.119 * \star$ & $0.129 * \star \star$ & $0.277^{\star \star \star}$ & & \\
\hline & & & & & $(0.0506)$ & $(0.0558)$ & $(0.0372)$ & $(0.0494)$ & & \\
\hline \multirow{2}{*}{$\begin{array}{l}\text { Clustering } \\
\text { coef. }\end{array}$} & & & & & & & & & $0.336^{* * *}$ & . \\
\hline & & & & & & & & & $(0.0277)$ & 1 \\
\hline \multirow[t]{2}{*}{ Mills ratio } & -0.00870 & $6.23 e-05$ & 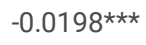 & $-0.0404^{\star \star \star}$ & $-0.0167 * \star$ & 0.00264 & $-0.0220 * \star \star$ & $-0.0448^{\star \star \star}$ & $0.0271 * * \star$ & \\
\hline & $(0.00708)$ & $(0.0115)$ & $(0.00735)$ & $(0.00735)$ & $(0.00766)$ & $(0.0124)$ & $(0.00756)$ & $(0.00777)$ & $(0.00754)$ & 1 \\
\hline \multirow[t]{2}{*}{ Size } & $0.0676^{\star \star *}$ & -0.00181 & $-0.0147 * *$ & $0.267 * \star \star *$ & $0.0632^{\star * \star}$ & -0.000811 & $-0.0159 * *$ & $0.267 * \star \star *$ & $0.0284^{\star \star \star}$ & 1 \\
\hline & $(0.00769)$ & $(0.00942)$ & $(0.00725)$ & $(0.00827)$ & $(0.00784)$ & $(0.00963)$ & $(0.00720)$ & $(0.00846)$ & $(0.00736)$ & 1 \\
\hline \multirow[t]{2}{*}{ Age } & 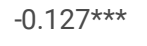 & 0.0146 ** & $0.236^{\star \star \star}$ & 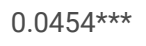 & 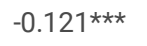 & $0.0126^{*}$ & $0.238^{\star \star \star}$ & $0.0500 * * \star$ & $-0.101 * \star *$ & 1 \\
\hline & $(0.00680)$ & $(0.00677)$ & $(0.00542)$ & $(0.00640)$ & $(0.00695)$ & $(0.00693)$ & $(0.00542)$ & $(0.00654)$ & $(0.00727)$ & 1 \\
\hline \multirow[t]{2}{*}{ Latitude } & $0.0419 * \star \star$ & -0.00817 & $0.0554 \star \star \star *$ & $0.0612^{\star \star \star}$ & $0.0626^{\star \star \star}$ & $-0.0141 *$ & $0.0618^{* * *}$ & $0.0771^{\star \star \star *}$ & $0.0362^{\star \star \star}$ & . \\
\hline & $(0.00658)$ & $(0.00671)$ & $(0.00629)$ & $(0.00721)$ & $(0.00700)$ & $(0.00768)$ & $(0.00659)$ & $(0.00761)$ & $(0.00702)$ & 1 \\
\hline \multirow[t]{2}{*}{ Longitude } & 0.00472 & -0.00744 & 0.00464 & $-0.0335^{\star \star \star}$ & $0.0391^{\star \star \star}$ & $-0.0193^{\star \star}$ & $0.0161^{\star *}$ & -0.00633 & 0.0108 & . \\
\hline & $(0.00657)$ & $(0.00722)$ & $(0.00629)$ & $(0.00722)$ & $(0.00741)$ & $(0.00872)$ & $(0.00691)$ & $(0.00820)$ & $(0.00687)$ & 1 \\
\hline \multirow[t]{2}{*}{ Constant } & $-0.168^{\star \star \star}$ & $0.0943^{\star \star}$ & $-0.224^{\star \star \star}$ & $0.380 * \star \star$ & $-0.135^{\star \star \star}$ & $0.0863^{\star}$ & $-0.215^{\star \star \star}$ & $0.412^{\star \star \star}$ & $-0.446^{\star \star \star}$ & 1 \\
\hline & $(0.0268)$ & $(0.0423)$ & $(0.0337)$ & $(0.0461)$ & $(0.0302)$ & $(0.0451)$ & $(0.0347)$ & $(0.0488)$ & $(0.0278)$ & 1 \\
\hline $\begin{array}{l}\text { Sector } \\
\text { controls }\end{array}$ & Yes & Yes & Yes & Yes & Yes & Yes & Yes & Yes & Yes & ' \\
\hline Observations & 34,556 & 30,741 & 35,858 & 32,201 & 34,556 & 30,741 & 35,858 & 32,201 & 34,556 & \\
\hline R-squared & & 0.004 & 0.121 & 0.076 & & & 0.093 & & & \\
\hline
\end{tabular}

Robust standard errors in parentheses. ${ }^{* *} p<0.01,{ }^{* *} p<0.05, * p<0.1$

The two candidate instruments are poorly correlated with all dependent variables, where correlation is always below 0.1 , and correlated to a higher extent just with the three centrality measures of degree, eigenvector centrality and clustering coefficient. Hence, we conclude that board size is only a valid instrument for degree, whereas eigen board size is also valid for eigen centrality and clustering coefficient.

Table 7 displays the results as robust to the simultaneity problem obtained through the bias correction procedure. The new results differ substantially from those reported in Table 5. In fact, eigenvector centrality now displays a positive and significant effect on profitability, financial independence and productivity, and a negative and significant impact on the degree of indebtedness. The results associated to the clustering coefficient are now in line with those relating eigenvector centrality. In short, correcting for endogeneity brings results that are more clearly in favor of the hypothesis that centrality and cohesion in the network matter in determining the performance of the network under all respects.

These results suggest that the ID is endogenously determined (RQ1) and that neglecting this source of endogeneity has an impact on the estimates (RQ2) when GLS (or OLS) are used instead of 2SLS procedures. Finally, we find that local size measures based on ID can be used as valid instruments for controlling endogeneity (RQ3). 
We inspect how the relation between performance and centrality measures varies across groups of firms of different sizes. Given the relatively small difference in the average values of centrality measures for micro and small firms, we only perform three blocks of results for micro and small firms, medium firms and large firms (Tables $8 \mathrm{a}, 8 \mathrm{~b}$ and $8 \mathrm{c}$ respectively). Our findings suggest that occupying central positions in the network matters more for small firms compared to medium and large ones, which provides a reply to the RQ4.

Endogeneity issues are also found to have a considerable impact on the results when they are analyzed by firm size. Appendix A3 reports results by size not controlling for the possible sources of endogeneity. In other words, they are produced by using the method of generalized least squares. For instance, the coefficient relating eigen vector centrality has often opposite sign with respect to the regressions robust to endogeneity. This becomes negative while remaining significant for financial independence and productivity and it remains negative but completely loses significance in the case of indebtedness. Our results indicate that the estimation bias is larger for firms of smaller size in GLS (or OLS) analysis where ID endogeneity is not treated (RQ5).

Table 8.a Heckman two-stage least square regression results for small firms ( $<50$ employess)

(1)

(2)

(3)

(4)

(5)

(6)

(7)

(8)

\begin{tabular}{|c|c|c|c|c|c|c|c|c|}
\hline VARIABLES & ROE & Debt/EBITDA & $\begin{array}{l}\text { Financial } \\
\text { independence }\end{array}$ & Productivity & ROE & Debt/EBITDA & $\begin{array}{l}\text { Financial } \\
\text { independence }\end{array}$ & Productivity \\
\hline \multirow[t]{2}{*}{ Degree } & $-0.316^{\star \star \star}$ & 0.0543 & $-0.0925^{\star \star \star}$ & $-0.0587^{\star}$ & $-0.126 * * \star$ & 0.0160 & -0.0152 & -0.00468 \\
\hline & $(0.0333)$ & $(0.0356)$ & $(0.0330)$ & $(0.0353)$ & $(0.0131)$ & $(0.0161)$ & $(0.0133)$ & $(0.0165)$ \\
\hline \multirow{2}{*}{$\begin{array}{l}\text { Eigen } \\
\text { centrality }\end{array}$} & 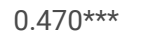 & $-0.0838^{*}$ & $0.178 * \star \star$ & 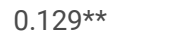 & & & & \\
\hline & $(0.0631)$ & $(0.0460)$ & $(0.0509)$ & $(0.0502)$ & & & & \\
\hline \multirow{2}{*}{$\begin{array}{l}\text { Clustering } \\
\text { coef. }\end{array}$} & & & & & $0.367 * \star \star$ & $-0.0787^{\star}$ & $0.160^{\star \star \star}$ & $0.126^{\star \star *}$ \\
\hline & & & & & $(0.0390)$ & $(0.0422)$ & $(0.0419)$ & $(0.0458)$ \\
\hline \multirow[t]{2}{*}{ Mills ratio } & -0.00980 & 0.00777 & $-0.0224 * \star \star$ & 0.00128 & $0.0287 * \star \star$ & -0.000579 & -0.00639 & $0.0135^{\star}$ \\
\hline & $(0.00808)$ & $(0.00669)$ & $(0.00840)$ & $(0.00848)$ & $(0.00802)$ & $(0.00678)$ & $(0.00790)$ & $(0.00802)$ \\
\hline \multirow[t]{2}{*}{ Size } & $0.116^{\star \star \star}$ & $0.0234^{\star *}$ & 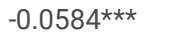 & $0.529 * \star \star$ & $0.0942^{\star \star \star}$ & $0.0276^{\star \star \star}$ & $-0.0692^{\star \star \star}$ & $0.519 \star \star \star *$ \\
\hline & $(0.0120)$ & $(0.0102)$ & $(0.0113)$ & $(0.0138)$ & $(0.0118)$ & $(0.0102)$ & $(0.0112)$ & $(0.0140)$ \\
\hline \multirow[t]{2}{*}{ Age } & $-0.148^{\star \star \star}$ & 0.0113 & $0.263^{\star \star \star}$ & $0.0200^{\star \star \star}$ & $-0.127^{\star \star \star}$ & 0.00679 & $0.272^{\star \star \star}$ & $0.0261^{\star \star \star}$ \\
\hline & $(0.00832)$ & $(0.00756)$ & $(0.00662)$ & $(0.00768)$ & $(0.00888)$ & $(0.00757)$ & $(0.00704)$ & $(0.00805)$ \\
\hline \multirow[t]{2}{*}{ Latitude } & $0.0612^{\star \star \star}$ & -0.00684 & $0.0610^{\star \star \star}$ & 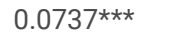 & $0.0451^{* \star *}$ & -0.00294 & $0.0539 * \star \star$ & $0.0685^{\star \star \star}$ \\
\hline & $(0.00806)$ & $(0.00811)$ & $(0.00793)$ & $(0.00873)$ & $(0.00857)$ & $(0.00826)$ & $(0.00786)$ & $(0.00864)$ \\
\hline \multirow[t]{2}{*}{ Longitude } & $0.0215^{\star \star}$ & -0.0137 & $0.0149 *$ & $-0.0291 * \star \star$ & 0.00897 & -0.00893 & 0.00817 & $-0.0355^{\star \star \star}$ \\
\hline & $(0.00846)$ & $(0.00925)$ & $(0.00818)$ & $(0.00877)$ & $(0.00848)$ & $(0.00913)$ & $(0.00785)$ & $(0.00832)$ \\
\hline \multirow[t]{2}{*}{ Constant } & $-0.133^{\star \star \star}$ & $0.126^{\star \star \star}$ & $-0.250 * \star \star$ & $0.543^{\star \star \star}$ & $-0.426 * \star \star$ & $0.194^{\star \star \star}$ & $-0.380^{\star \star \star}$ & $0.455^{\star \star \star}$ \\
\hline & $(0.0314)$ & $(0.0360)$ & $(0.0377)$ & $(0.0507)$ & $(0.0322)$ & $(0.0386)$ & $(0.0370)$ & $(0.0471)$ \\
\hline $\begin{array}{l}\text { Sector } \\
\text { controls }\end{array}$ & Yes & Yes & Yes & Yes & Yes & Yes & Yes & Yes \\
\hline Observations & 24,243 & 20,637 & 25,168 & 21,735 & 24,243 & 20,637 & 25,168 & 21,735 \\
\hline R-squared & & 0.000 & 0.096 & 0.131 & & 0.002 & 0.116 & 0.143 \\
\hline
\end{tabular}

Robust standard errors in parentheses. ${ }^{* *} p<0.01,{ }^{* *} p<0.05,{ }^{*} p<0.1$

Table 8.b Heckman two-stage least square regression results for medium firms ( $50 \leq$ employees $<250)$ 


\begin{tabular}{|c|c|c|c|c|c|c|c|c|}
\hline & (1) & (2) & (3) & (4) & (5) & (6) & (7) & (8) \\
\hline VARIABLES & ROE & Debt/EBITDA & $\begin{array}{l}\text { Financial } \\
\text { independence }\end{array}$ & Productivity & ROE & Debt/EBITDA & $\begin{array}{l}\text { Financial } \\
\text { independence }\end{array}$ & Productivity \\
\hline \multirow[t]{2}{*}{ Degree } & $-0.266^{\star \star \star}$ & $0.172^{\star \star}$ & -0.0247 & -0.0844 & $-0.0627 * \star \star$ & $0.0449 * \star$ & -0.00553 & -0.0129 \\
\hline & $(0.0587)$ & $(0.0758)$ & $(0.0513)$ & (0.0538) & (0.0158) & $(0.0213)$ & $(0.0149)$ & $(0.0142)$ \\
\hline \multirow{2}{*}{$\begin{array}{l}\text { Eigen } \\
\text { centrality }\end{array}$} & 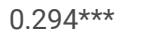 & $-0.181^{\star \star}$ & 0.0279 & $0.102^{\star}$ & & & & \\
\hline & $(0.0663)$ & $(0.0796)$ & $(0.0557)$ & $(0.0586)$ & & & & \\
\hline \multirow[t]{2}{*}{$\begin{array}{l}\text { Clustering } \\
\text { coef. }\end{array}$} & & & & & $0.368^{\star \star \star}$ & $-0.218^{\star \star}$ & 0.0323 & $0.118^{*}$ \\
\hline & & & & & $(0.0696)$ & $(0.0864)$ & $(0.0637)$ & $(0.0624)$ \\
\hline \multirow[t]{2}{*}{ Mills ratio } & -0.0760 & 0.0398 & $-0.185^{\star \star \star}$ & $-0.113^{\star \star \star}$ & -0.00919 & -0.0127 & 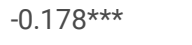 & $-0.0891^{\star \star \star *}$ \\
\hline & $(0.0473)$ & $(0.0454)$ & $(0.0350)$ & $(0.0326)$ & $(0.0437)$ & $(0.0354)$ & $(0.0310)$ & $(0.0279)$ \\
\hline \multirow[t]{2}{*}{ Size } & $0.133^{\star \star \star}$ & -0.00281 & 0.0260 & 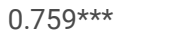 & 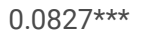 & 0.0174 & 0.0220 & $0.743^{\star \star \star}$ \\
\hline & $(0.0231)$ & $(0.0302)$ & (0.0192) & (0.0198) & $(0.0236)$ & $(0.0306)$ & (0.0198) & $(0.0208)$ \\
\hline \multirow[t]{2}{*}{ Age } & 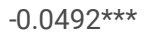 & $0.0283^{\star \star}$ & $0.204^{\star \star \star}$ & $0.0923^{\star \star \star}$ & -0.0235 & 0.0115 & $0.206^{\star \star \star}$ & $0.101^{\star \star \star}$ \\
\hline & $(0.0143)$ & $(0.0142)$ & $(0.0105)$ & $(0.00977)$ & (0.0159) & $(0.0145)$ & $(0.0113)$ & (0.0105) \\
\hline \multirow[t]{2}{*}{ Latitude } & $0.0458 * \star \star$ & -0.0330 ** & $0.0428 * \star \star$ & $0.0389 * \star \star$ & 0.00191 & -0.00559 & $0.0389 * \star \star$ & $0.0250 * \star$ \\
\hline & $(0.0148)$ & $(0.0141)$ & $(0.0128)$ & $(0.0116)$ & $(0.0152)$ & $(0.0125)$ & $(0.0124)$ & (0.0109) \\
\hline \multirow[t]{2}{*}{ Longitude } & $0.0618^{\star \star \star}$ & 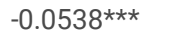 & 0.00948 & -0.00711 & 0.0128 & $-0.0237^{*}$ & 0.00527 & $-0.0225^{\star \star}$ \\
\hline & $(0.0156)$ & $(0.0179)$ & (0.0139) & $(0.0135)$ & $(0.0144)$ & $(0.0138)$ & (0.0119) & $(0.0112)$ \\
\hline \multirow[t]{2}{*}{ Constant } & -0.208 ** & -0.127 & -0.00623 & $-0.864^{\star \star \star}$ & 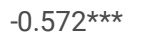 & 0.111 & -0.0405 & $-0.987^{\star \star \star}$ \\
\hline & $(0.0952)$ & $(0.134)$ & $(0.105)$ & $(0.112)$ & $(0.0782)$ & $(0.103)$ & (0.0899) & $(0.0926)$ \\
\hline $\begin{array}{l}\text { Sector } \\
\text { controls }\end{array}$ & Yes & Yes & Yes & Yes & Yes & Yes & Yes & Yes \\
\hline Observations & 7,818 & 7,654 & 8,110 & 8,063 & 7,818 & 7,654 & 8,110 & 8,063 \\
\hline R-squared & & & 0.172 & 0.357 & & & 0.177 & 0.369 \\
\hline
\end{tabular}

Robust standard errors in parentheses. ${ }^{* *} p<0.01,{ }^{* *} p<0.05,{ }^{*} p<0.1$

Table 8.c Heckman two -stage least square regression results for large firms (employees $\geq 250$ ) 
(1) (2) (3)

VARIABLES

ROE
Debt/EBITDA Financial independence
(4)

Productivity ROE
(6)

Debt/EBITDA
(7)

Financia independence
(8)

Productivity

\begin{tabular}{|c|c|c|c|c|c|c|c|c|}
\hline Degree & -0.300 ** & 0.214 & 0.0837 & $-0.409 * \star$ & 0.00542 & -0.00558 & -0.0161 & -0.00836 \\
\hline & $(0.131)$ & $(0.312)$ & $(0.0996)$ & (0.189) & $(0.0158)$ & $(0.0664)$ & $(0.0114)$ & $(0.0149)$ \\
\hline \multirow{2}{*}{$\begin{array}{l}\text { Eigen } \\
\text { centrality }\end{array}$} & 0.520 ** & -0.359 & -0.170 & 0.674 ** & & & & \\
\hline & $(0.229)$ & $(0.421)$ & $(0.166)$ & $(0.343)$ & & & & \\
\hline \multirow{2}{*}{$\begin{array}{l}\text { Clustering } \\
\text { coef. }\end{array}$} & & & & & $0.275^{\star \star \star}$ & -0.182 & -0.0864 & $0.388^{* \star *}$ \\
\hline & & & & & $(0.0805)$ & (0.198) & $(0.0781)$ & $(0.107)$ \\
\hline \multirow[t]{2}{*}{ Mills ratio } & $0.241^{\star \star}$ & -0.221 ** & 0.0256 & $-0.312^{\star \star}$ & 0.0534 & -0.0726 & 0.0856 & $-0.663^{\star \star \star}$ \\
\hline & $(0.118)$ & $(0.112)$ & $(0.104)$ & $(0.158)$ & $(0.127)$ & $(0.213)$ & $(0.116)$ & $(0.180)$ \\
\hline \multirow[t]{2}{*}{ Size } & $0.127 * \star$ & -0.0353 & 0.00549 & $0.627 * \star \star$ & 0.0189 & 0.0371 & $0.0399 *$ & $0.481^{* * *}$ \\
\hline & $(0.0500)$ & $(0.0563)$ & $(0.0367)$ & $(0.0719)$ & $(0.0290)$ & $(0.0711)$ & $(0.0208)$ & $(0.0316)$ \\
\hline \multirow[t]{2}{*}{ Age } & 0.0129 & -0.0690 & $0.134^{\star \star \star}$ & $0.108^{\star \star \star}$ & -0.00227 & -0.0581 & $0.138^{\star \star \star}$ & 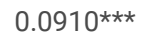 \\
\hline & $(0.0281)$ & $(0.0548)$ & (0.0197) & $(0.0271)$ & $(0.0267)$ & $(0.0459)$ & (0.0195) & $(0.0233)$ \\
\hline \multirow[t]{2}{*}{ Latitude } & $0.101^{\star \star}$ & -0.0655 & 0.0315 & $0.0927^{\star *}$ & 0.0217 & -0.00725 & $0.0559 * \star$ & -0.0166 \\
\hline & $(0.0402)$ & $(0.0762)$ & $(0.0306)$ & $(0.0467)$ & $(0.0240)$ & $(0.0420)$ & $(0.0257)$ & $(0.0287)$ \\
\hline \multirow[t]{2}{*}{ Longitude } & $0.114^{\star \star \star}$ & -0.0156 & -0.0159 & 0.120 ** & $0.0377 *$ & 0.0379 & 0.00836 & 0.0141 \\
\hline & $(0.0414)$ & $(0.0704)$ & $(0.0312)$ & $(0.0542)$ & $(0.0209)$ & $(0.0260)$ & $(0.0223)$ & $(0.0237)$ \\
\hline \multirow[t]{2}{*}{ Constant } & $-0.397 * \star \star$ & -0.0202 & -0.461 ** & -1.360 *** & $-0.601 * \star \star *$ & 0.139 & $-0.398 * \star$ & $-1.676^{\star \star \star}$ \\
\hline & $(0.118)$ & $(0.305)$ & $(0.190)$ & (0.199) & $(0.106)$ & $(0.161)$ & (0.192) & $(0.179)$ \\
\hline $\begin{array}{l}\text { Sector } \\
\text { controls }\end{array}$ & Yes & Yes & Yes & Yes & Yes & Yes & Yes & Yes \\
\hline Observations & 2,474 & 2,428 & 2,539 & 2,383 & 2,474 & 2,428 & 2,539 & 2,383 \\
\hline R-squared & & & 0.108 & & & 0.050 & 0.176 & 0.206 \\
\hline
\end{tabular}

Robust standard errors in parentheses. ${ }^{* *} p<0.01,{ }^{* *} p<0.05,{ }^{*} p<0.1$

Table 9.a Generalized least square regression results for small firms (<50 employess) 


\begin{tabular}{|c|c|c|c|c|c|c|c|c|}
\hline & (1) & (2) & (3) & (4) & (5) & (6) & (7) & (8) \\
\hline VARIABLES & ROE & Debt/EBITDA & $\begin{array}{l}\text { Financial } \\
\text { independence }\end{array}$ & Productivity & ROE & Debt/EBITDA & $\begin{array}{l}\text { Financial } \\
\text { independence }\end{array}$ & Productivity \\
\hline \multirow[t]{2}{*}{ Degree } & $-0.0597 * \star \star$ & -0.0107 & $0.0488 * \star \star$ & $0.0489 * \star \star$ & $-0.0203^{\star \star \star}$ & -0.00663 & $0.0246 * \star \star$ & $0.0231^{\star \star *}$ \\
\hline & $(0.00733)$ & $(0.00821)$ & $(0.00676)$ & $(0.00845)$ & $(0.00703)$ & $(0.00706)$ & $(0.00600)$ & $(0.00739)$ \\
\hline \multirow{2}{*}{$\begin{array}{l}\text { Eigen } \\
\text { centrality }\end{array}$} & $0.0724^{\star \star \star}$ & 0.00384 & $-0.0213^{\star \star \star}$ & 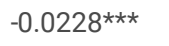 & & & & \\
\hline & $(0.00829)$ & $(0.00361)$ & $(0.00570)$ & $(0.00722)$ & & & & \\
\hline \multirow{2}{*}{$\begin{array}{l}\text { Clustering } \\
\text { coef. }\end{array}$} & & & & & $0.0143^{\star \star \star}$ & -0.00480 & $0.0310 * \star \star$ & $0.0272^{\star \star \star}$ \\
\hline & & & & & $(0.00550)$ & $(0.00688)$ & $(0.00539)$ & $(0.00586)$ \\
\hline \multirow[t]{2}{*}{ Size } & $0.0959 * \star \star$ & 0.0250 ** & 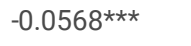 & $0.514^{\star \star \star}$ & $0.0906^{\star \star \star}$ & $0.0249 \star \star$ & 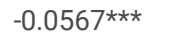 & $0.514^{\star \star \star}$ \\
\hline & $(0.00868)$ & $(0.00992)$ & $(0.00863)$ & $(0.0105)$ & $(0.00866)$ & $(0.0100)$ & $(0.00861)$ & $(0.0105)$ \\
\hline \multirow[t]{2}{*}{ Age } & $-0.144^{\star \star \star}$ & 0.0113 & $0.261^{\star \star \star}$ & $0.0219 * * *$ & $-0.142^{\star \star \star}$ & 0.0111 & $0.263^{\star \star \star}$ & $0.0233^{\star \star \star}$ \\
\hline & (0.00793) & $(0.00727)$ & $(0.00617)$ & $(0.00734)$ & $(0.00796)$ & $(0.00720)$ & $(0.00619)$ & $(0.00735)$ \\
\hline \multirow[t]{2}{*}{ Latitude } & $0.0500 * \star \star$ & -0.00408 & $0.0559 * \star \star$ & $0.0687^{\star \star \star *}$ & $0.0477^{\star \star \star}$ & -0.00414 & $0.0562^{\star \star \star}$ & $0.0690 \star \star \star *$ \\
\hline & $(0.00780)$ & $(0.00816)$ & $(0.00774)$ & $(0.00856)$ & $(0.00781)$ & $(0.00819)$ & $(0.00774)$ & $(0.00857)$ \\
\hline \multirow[t]{2}{*}{ Longitude } & 0.00659 & -0.00820 & 0.00530 & $-0.0373^{\star \star \star}$ & 0.00403 & -0.00847 & 0.00669 & $-0.0360 * \star \star$ \\
\hline & $(0.00774)$ & $(0.00915)$ & $(0.00773)$ & $(0.00825)$ & $(0.00777)$ & $(0.00915)$ & $(0.00774)$ & $(0.00826)$ \\
\hline \multirow[t]{2}{*}{ Constant } & $-0.241 * \star \star$ & $0.160 * \star \star$ & $-0.324^{\star \star *}$ & $0.506^{\star \star *}$ & $-0.263^{\star * \star}$ & $0.161^{\star * *}$ & $-0.331^{\star \star \star \star}$ & $0.502^{\star \star \star}$ \\
\hline & $(0.0243)$ & $(0.0318)$ & $(0.0326)$ & $(0.0462)$ & $(0.0243)$ & $(0.0319)$ & $(0.0325)$ & $(0.0462)$ \\
\hline $\begin{array}{l}\text { Sector } \\
\text { controls }\end{array}$ & Yes & Yes & Yes & Yes & Yes & Yes & Yes & Yes \\
\hline Observations & 24,243 & 20,637 & 25,168 & 21,735 & 24,243 & 20,637 & 25,168 & 21,735 \\
\hline R-squared & 0.059 & 0.008 & 0.135 & 0.154 & 0.055 & 0.008 & 0.136 & 0.154 \\
\hline
\end{tabular}

Robust standard errors in parentheses. ${ }^{* *} p<0.01,{ }^{* *} p<0.05,{ }^{*} p<0.1$

Table 9.b Generalized least square regression results for medium firms ( $50 \leq$ employees $<250$ ) 
(1)

VARIABLES
(2)

Debt/EBITDA
(3)

Financial independence
(4) (5)

Productivity ROE
(6)

Debt/EBITDA
(7)

Financial independence
(8)

Productivity

\begin{tabular}{|c|c|c|c|c|c|c|c|c|}
\hline Degree & $-0.0595^{\star \star \star}$ & 0.0142 & $0.0183^{*}$ & $0.0178^{* *}$ & 0.00603 & 0.0119 & -0.000872 & $0.0141^{\star *}$ \\
\hline & $(0.0102)$ & $(0.0139)$ & $(0.00943)$ & $(0.00809)$ & $(0.0114)$ & $(0.0101)$ & $(0.00783)$ & $(0.00664)$ \\
\hline \multirow{2}{*}{$\begin{array}{l}\text { Eigen } \\
\text { centrality }\end{array}$} & $0.0766^{\star * *}$ & -0.00815 & $-0.0190 * \star *$ & -0.00500 & & & & \\
\hline & $(0.00681)$ & $(0.00560)$ & $(0.00464)$ & $(0.00378)$ & & & & \\
\hline \multirow{2}{*}{$\begin{array}{l}\text { Clustering } \\
\text { coef. }\end{array}$} & & & & & -0.00373 & $-0.0200^{\star}$ & $0.0150 *$ & -0.00221 \\
\hline & & & & & $(0.00935)$ & $(0.0107)$ & $(0.00862)$ & $(0.00728)$ \\
\hline \multirow[t]{2}{*}{ Size } & $0.122^{\star \star \star}$ & 0.00692 & $0.0825^{\star \star \star}$ & $0.780 * \star \star$ & $0.111^{\star \star *}$ & 0.00875 & $0.0841^{* * *}$ & $0.781 * * *$ \\
\hline & $(0.0177)$ & $(0.0240)$ & $(0.0154)$ & $(0.0160)$ & $(0.0177)$ & $(0.0239)$ & $(0.0154)$ & $(0.0159)$ \\
\hline \multirow[t]{2}{*}{ Age } & $-0.0492 * \star *$ & $0.0269 * *$ & $0.195^{\star \star \star}$ & $0.0889 * * *$ & $-0.0484 * \star \star *$ & $0.0254^{*}$ & $0.195^{\star \star \star}$ & $0.0886^{* * *}$ \\
\hline & $(0.0140)$ & $(0.0135)$ & $(0.0104)$ & $(0.00950)$ & $(0.0140)$ & $(0.0135)$ & $(0.0104)$ & $(0.00950)$ \\
\hline \multirow[t]{2}{*}{ Latitude } & $0.0287^{\star \star}$ & -0.0162 & $0.0524 * \star \star$ & $0.0364^{\star \star \star}$ & 0.0209 & -0.0143 & $0.0537 \star \star \star *$ & $0.0370^{* * *}$ \\
\hline & $(0.0133)$ & $(0.0110)$ & $(0.0117)$ & $(0.0102)$ & $(0.0133)$ & $(0.0110)$ & $(0.0117)$ & $(0.0102)$ \\
\hline \multirow[t]{2}{*}{ Longitude } & $0.0325^{\star \star}$ & $-0.0289 * *$ & 0.00522 & $-0.0201 *$ & $0.0216^{*}$ & $-0.0272^{\star \star}$ & 0.00746 & $-0.0194 *$ \\
\hline & $(0.0129)$ & $(0.0134)$ & $(0.0120)$ & $(0.0112)$ & $(0.0130)$ & $(0.0133)$ & $(0.0119)$ & $(0.0111)$ \\
\hline \multirow[t]{2}{*}{ Constant } & $-0.395^{\star \star \star}$ & 0.0123 & $-0.188^{* *}$ & $-1.021^{\star \star \star}$ & $-0.433^{\star * \star}$ & 0.0237 & $-0.184^{\star *}$ & $-1.018^{\star * *}$ \\
\hline & $(0.0624)$ & $(0.0952)$ & $(0.0862)$ & $(0.0908)$ & $(0.0628)$ & $(0.0950)$ & $(0.0861)$ & $(0.0909)$ \\
\hline $\begin{array}{l}\text { Sector } \\
\text { controls }\end{array}$ & Yes & Yes & Yes & Yes & Yes & Yes & Yes & Yes \\
\hline Observations & 7,819 & 7,655 & 8,111 & 8,064 & 7,819 & 7,655 & 8,111 & 8,064 \\
\hline R-squared & 0.065 & 0.042 & 0.176 & 0.389 & 0.048 & 0.043 & 0.175 & 0.389 \\
\hline
\end{tabular}

Robust standard errors in parentheses. ${ }^{* *} p<0.01,{ }^{* *} p<0.05,{ }^{*} p<0.1$

Table 9.c Generalized least square regression results for large firms (employees $\geq 250$ ) 
(1) (2) (3)

$\mathrm{ROE}$
Debt/EBITDA Financial independence
(4) (5)

Productivity ROE
(6)

Debt/EBITDA
(7)

Financial independence
(8)

Productivity

\begin{tabular}{|c|c|c|c|c|c|c|c|c|}
\hline Degree & $-0.0260 *$ & 0.0327 & -0.00913 & $0.0258^{\star \star}$ & 0.0159 & 0.0261 & $-0.0188^{\star}$ & $0.0244^{* *}$ \\
\hline & $(0.0146)$ & $(0.0483)$ & $(0.0112)$ & $(0.0127)$ & (0.0168) & $(0.0409)$ & $(0.00981)$ & $(0.0106)$ \\
\hline \multirow{2}{*}{$\begin{array}{l}\text { Eigen } \\
\text { centrality }\end{array}$} & $0.0723^{\star \star \star}$ & -0.0126 & $-0.0114^{\star \star}$ & 0.00156 & & & & \\
\hline & $(0.0233)$ & $(0.0144)$ & $(0.00527)$ & $(0.00563)$ & & & & \\
\hline \multirow{2}{*}{$\begin{array}{l}\text { Clustering } \\
\text { coef. }\end{array}$} & & & & & $0.0317^{\star}$ & -0.0147 & $0.0281^{\star}$ & $0.0274^{*}$ \\
\hline & & & & & $(0.0172)$ & $(0.0281)$ & $(0.0154)$ & $(0.0141)$ \\
\hline \multirow[t]{2}{*}{ Size } & 0.0297 & 0.0410 & 0.0232 & $0.517 * * \star$ & 0.0183 & 0.0423 & 0.0264 & 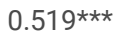 \\
\hline & $(0.0248)$ & $(0.0588)$ & $(0.0192)$ & $(0.0286)$ & $(0.0250)$ & $(0.0600)$ & $(0.0191)$ & $(0.0284)$ \\
\hline \multirow[t]{2}{*}{ Age } & -0.00301 & -0.0565 & $0.134 * \star \star$ & $0.0962^{\star \star \star}$ & -0.00456 & -0.0563 & $0.134^{\star \star \star}$ & $0.0965^{\star \star \star}$ \\
\hline & $(0.0267)$ & $(0.0473)$ & (0.0193) & $(0.0225)$ & $(0.0267)$ & $(0.0471)$ & $(0.0193)$ & $(0.0225)$ \\
\hline \multirow[t]{2}{*}{ Latitude } & 0.0302 & -0.00765 & $0.0458^{\star}$ & $0.0387^{\star}$ & 0.0214 & -0.00601 & $0.0469 *$ & $0.0382^{\star}$ \\
\hline & $(0.0230)$ & $(0.0424)$ & $(0.0243)$ & $(0.0217)$ & $(0.0227)$ & $(0.0417)$ & $(0.0243)$ & $(0.0219)$ \\
\hline \multirow[t]{2}{*}{ Longitude } & $0.0427^{\star *}$ & 0.0384 & 0.00831 & 0.0196 & 0.0323 & 0.0401 & 0.0104 & 0.0198 \\
\hline & $(0.0207)$ & $(0.0255)$ & $(0.0223)$ & $(0.0211)$ & $(0.0207)$ & $(0.0252)$ & $(0.0221)$ & $(0.0211)$ \\
\hline \multirow[t]{2}{*}{ Constant } & $-0.417^{\star \star \star}$ & -0.0505 & $-0.399 * \star$ & $-1.694^{\star \star \star}$ & $-0.454^{\star \star \star}$ & -0.0378 & $-0.408^{\star \star}$ & $-1.713^{\star \star \star}$ \\
\hline & $(0.0686)$ & $(0.179)$ & $(0.184)$ & $(0.140)$ & $(0.0714)$ & $(0.170)$ & $(0.184)$ & $(0.140)$ \\
\hline $\begin{array}{l}\text { Sector } \\
\text { controls }\end{array}$ & Yes & Yes & Yes & Yes & Yes & Yes & Yes & Yes \\
\hline Observations & 2,495 & 2,450 & 2,580 & 2,403 & 2,495 & 2,450 & 2,580 & 2,403 \\
\hline R-squared & 0.089 & 0.068 & 0.195 & 0.362 & 0.074 & 0.068 & 0.196 & 0.362 \\
\hline
\end{tabular}

Robust standard errors in parentheses. ${ }^{* *} p<0.01,{ }^{* *} p<0.05,{ }^{*} p<0.1$

\section{Conclusions}

In this paper we study the affiliation network of firms and boards of directors. The descriptive analysis provides itself interesting insight on the nature of interlocking directorates. First of all, it appears that the majority of firms are "islands", that is, they are not connected to any other firm across the network. Further, the degree of connectedness decays rapidly in the number of observations.

We show that the pattern of decay follows a power law, confirming the non-random nature in the formation of the ties. We discuss the contribution of three factors affecting the formation of the network which are belonging to a specific sector, the geographic distance between vertices and the size of the firm. Our findings suggest that the majority of the links occur within the firm's geographical neighborhood, $40 \%$ take place in a range of $10 \mathrm{Km}, 66 \%$ in a range of $100 \mathrm{~km}$ and more than $75 \%$ in a range of $200 \mathrm{Km}$. And, with respect to the interlocking sector composition, we find that there are some types of activities that, for their nature, are more central than others. These are the provision of electric energy and gas, financial and insurance activities, and ICT-related activities. Firms operating in these sectors not only tend to exhibit higher degree, but also eigenvector centrality and clustering coefficient.

The third determinant in the pattern of formation of the network is size. Larger firms on average have higher probability of being part of the ID network with respect to medium and small firms. The participation patterns do not seem to vary substantially between small and micro firms.

We then conduct an econometric analysis to assess the impact of the positioning of the firm in the network on its performance. We find confirmation that results obtained through the GLS method suffer a bias due to a double source of endogeneity between performance and centrality metrics. Here, the sample selection effect of firms is part of the network and simultaneity, the determination of the centrality measures, and performance. To deal with this, we implement a regression strategy consisting of in first estimating the Mills' ratio through an auxiliary probit regression and then implementing a two stage least square that incorporates the estimated ratios in the second stage, as per Woolridge 2010. Following the literature, we also use board size as an instrument, which is found to be valid for degree. We then propose a new instrument for eigen centrality and the clustering coefficient where the instrument is obtained by considering the overall number of directors sitting in the boards of the degree-neighbors of the firm.

Our results suggest that eigenvector centrality and the clustering coefficient have a positive and robust effect on profitability, financial independence and productivity and a negative effect on the degree of indebtedness of the firm. Interlocking, even if rarer, seems to be more beneficial to small firms with respect 
to large ones.

\section{Declarations}

Acknowledgements

We thank for the useful comments the participants at the XVII Workshop CMET05, Italy 2020.

\section{Funding}

This research is supported by the Venice centre in Economic and Risk Analytics (VERA) at University Ca' Foscari of Venice.

\section{Contribution}

Tullio Buccellato, Riccardo Busin, Roberto Casarin and Giancarlo Corò have contributed equally to this work.

\section{Consent to participate}

Not applicable

\section{Consent to publication}

Not applicable

\section{Conflicts of interests}

The opinions and views expressed in this paper by the authors do not reflect in any way the opinions and views of Confindustria as an institution. The authors have no conflicts of interest to declare that are relevant to the content of this article.

\section{Availability of data and materials}

The datasets generated and analysed during the current study are available upon request to the corresponding author.

\section{References}

1. Abdelbadie, R. A., and Salama, A., 2019. Corporate governance and financial stability in US banks. Do indirect interlocks matter? Journal of Business Research, 104:85-105.

2. Bailey, M., Cao, R., Kuchler, T., Stroebel, J., \& Wong, A., (2018), Social Connectedness: Measurement, Determinants, and Effects. Journal of Economic Perspectives, 32(3):259-280.

3. Bellenzier, L., \& Grassi, R., 2013. Interlocking directorates in Italy: persistent links in network dynamics, Journal of Economic Interaction and Coordination, 1-20.

4. Boyd B., 1990. Corporate Linkages and Organizational Environment: A Test of the Resource Dependence Model, Strategic Management Journal, 11(6): 419-430.

5. Brauna M., Briones I., \& Islasa G., 2019. Interlocking directorates, access to credit, and business performance in Chile during early industrialization, Journal of Business Research, 105: 381-388.

6. Brunninge, O., Nordqvist, M., Wiklund, J., 2007. Corporate Governance and Strategic Change in SMEs: The Effects of Ownership, Board Composition and Top Management Teams, Small Business Economics, 29: 295-308, Springer.

7. Buscle, G., 2008. Controlling for endogeneity with instrumental variables in strategic management research, Strategic Organization, 6(3):285-327.

8. Caiazza, R. \& Simoni, M., 2015. Directors' role in inter-organizational networks, Corporate Governance, 15(4), 508-516.

9. Caiazza, R. \& Simoni, M., 2019. Directorate ties: a bibliometric analysis, Management Decision, 57(10), 2837-2851.

10. Croci, E., \& Grassi, R., 2014. The economic effect of interlocking directorates in Italy: new evidence using centrality measures. Computational and Mathematical Organization Theory, 20:89-112.

11. Cronin, B., 2011. Networks of corporate power revisited. Procedia Social and Behavioral Sciences, 10:43-51.

12. Dooley, P., (1969). The Interlocking Directorate. American Economic Review, 59(3):314-23

13. Huse, M., 1994. Board-Management Relations in Small Firms: The Paradox of Simultaneous Independence and Interdependence, Small Business Economics, Feb., 1994, Vol. 6, No. 1 (Feb., 1994), pp. 55-72, Springer.

14. Koka B., Prescott J., 2008. Designing alliance networks: the influence of network position, environmental change, and strategy on firm performance. Strategic Management Journal, 29:639-661.

15. Larcker D., So E., \& Wang C., 2013. Boardroom centrality and firm performance. Journal of Accounting and Economics, 55:225-250.

16. Lester, R.H., Cannella A.A., 2006. Interorganizational Familiness: How Family Firms Use Interlocking Directorates to Build Community-Level Social Capital. Entrepreneurship Theory and Practice, 30(6):755-775. 
17. Mazzola, E., Perrone, G., \& Kamuriwo, D. S., (2016). The interaction between inter-firm and interlocking directorate networks on firm's new product development outcomes. Journal of Business Research, 69:672-682.

18. Mintz, B., Schwartz, M., 1981. Interlocking Directorates and Interest Group Formation. American Sociological Review, 46(6):851-869.

19. Mizruchi, M.S., 1996. What do interlocks do? An analysis critique, and assessment of research on interlocking directorates. Annual Review Sociology, 22(1):271-298.

20. Newman, M.E.J. (2010). Network - An introduction, Oxford University Press.

21. Non M., Franses H., 2007. Interlocking Boards and Firm Performance: Evidence from a New Panel Database, Working Paper.

22. Phan P., Soo H., \& Chi S., 2003. The performance impact of interlocking directorates: the case of Singapore. Journal of Managerial Issues, $15(3): 338-352$.

23. Roomens, A., Cuyvers, L., \& Deloof, M., (2007), Interlocking Directorates and Business Groups: Belgian Evidence, Working Paper.

24. Rossoni, L., Aranha, C.E., and Mendes-da-Silva W., 2018. Does the capital of social capital matter? Relational resources of the board and the performance of Brazilian companies. Journal of Management and Governance, 22:153-185.

25. Santos, R., Da Silveira A., \& Barros L., 2012. Board interlocking in Brazil: directors' participation in multiple companies and its effect on firm value and profitability. Latin American Business Review, 13(1):1-28.

26. Stokman, F.N., Ziegler, R., \& Scott J. (1985). Networks of Corporate Power: A Comparative Analysis of Ten Countries, Oxford, U.K., Polity Press.

27. Shivdasani, A., Fich E., 2004. Are Busy Boards Effective Monitors? ECGI Working Paper Series in Finance, 55: 1-50.

28. Uzzi, B., (1999). Embeddedness in the Making of Financial Capital: How Social Relations and Networks Benefit Firms Seeking Financing. American Sociological Review, 64(4):481-505.

29. Weemaes, S., Bruneel, J., Gaeremynck, A., Debrulle, J., 2020. Initial external knowledge sources and start-up growth, Small Business Economics, https://doi.org/10.1007/s11187-020-00428-7, Springer Science+Business Media LLC, part of Springer Nature 2020.

30. Wincent, J., Anokhin, S., \& Örtqvist, D., (2010). Does network board capital matter? A study of innovative performance. Journal of Business Research, 63:265-275.

31. Wooldridge, J.M., (2010), Econometric analysis of cross section and panel data, $2^{\text {nd }}$ Edition, The MIT Press, Cambridge Massachusetts, London England.

32. Zona, F., Luis R. G.-M., \& Withers, M.C., 2018. Board Interlocks and Firm Performance: Toward a Combined Agency-Resource Dependence Perspective. Journal of Management, 44:589-618.

\section{Figures}

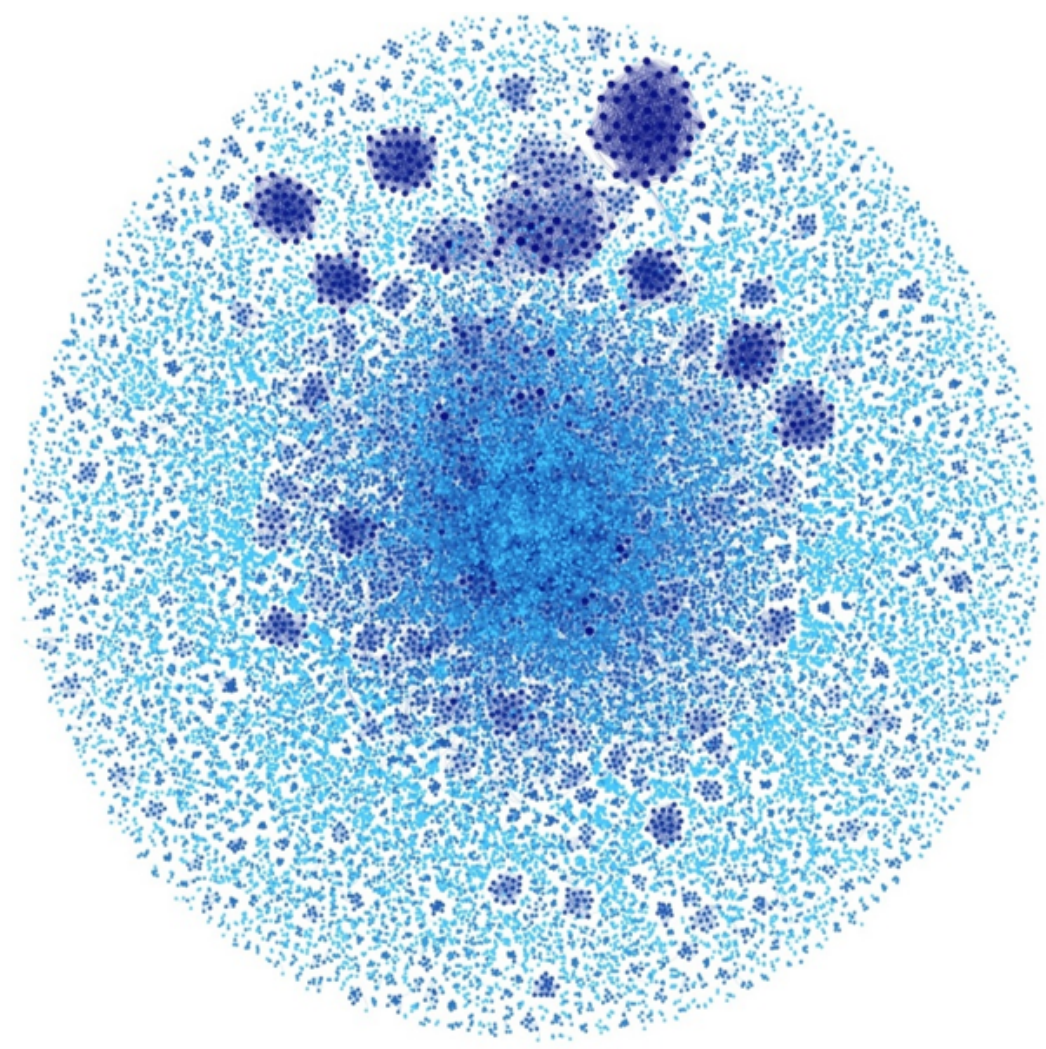

\section{Figure 1}

The interlocking network (larger node size and darker node color indicate higher degree)

Source: authors' calculations based on Aida Bureau Van Dijk. 


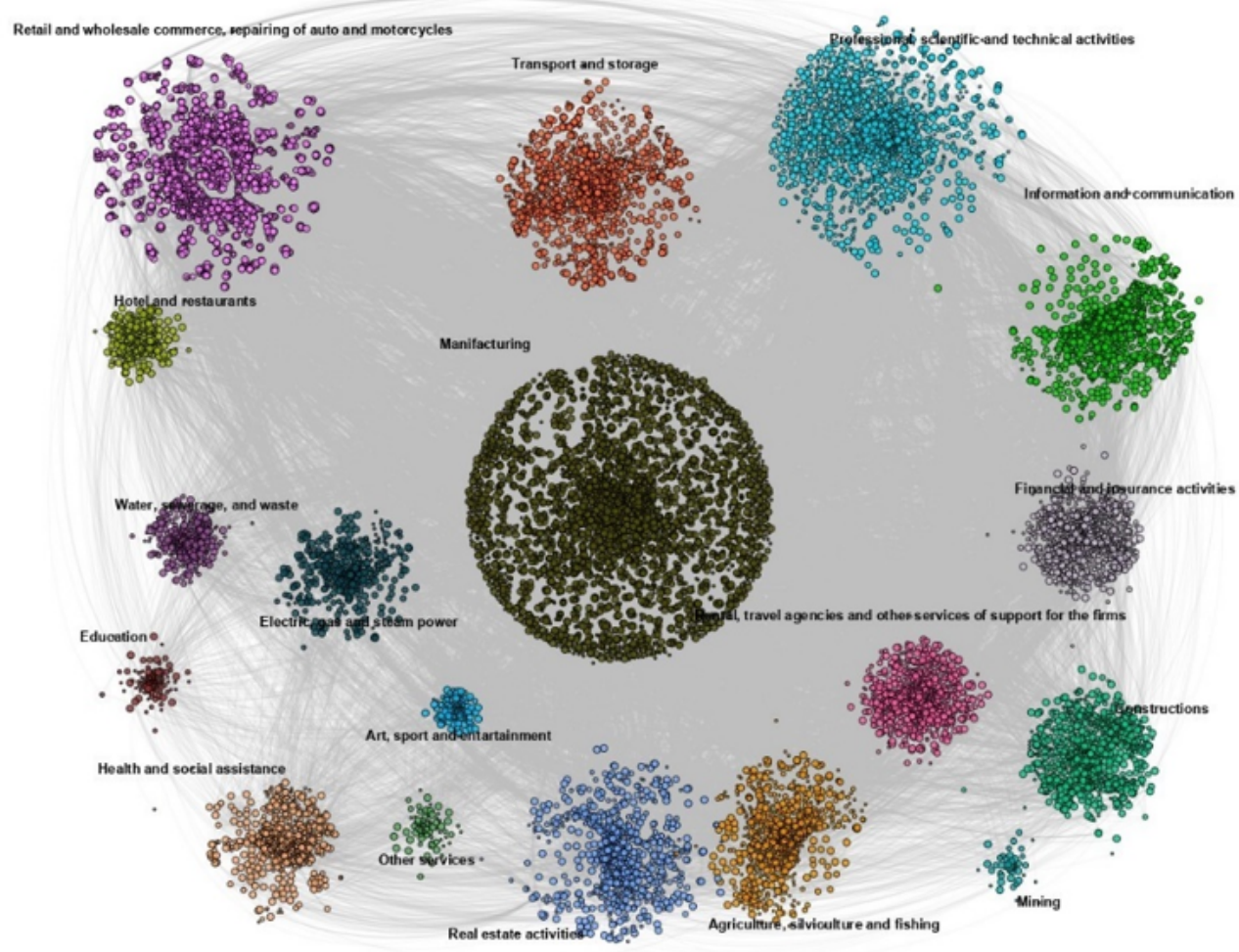

\section{Figure 2}

The sector decomposition (different colors) of the giant components

Source: authors' calculations based on Aida Bureau Van Dijk.

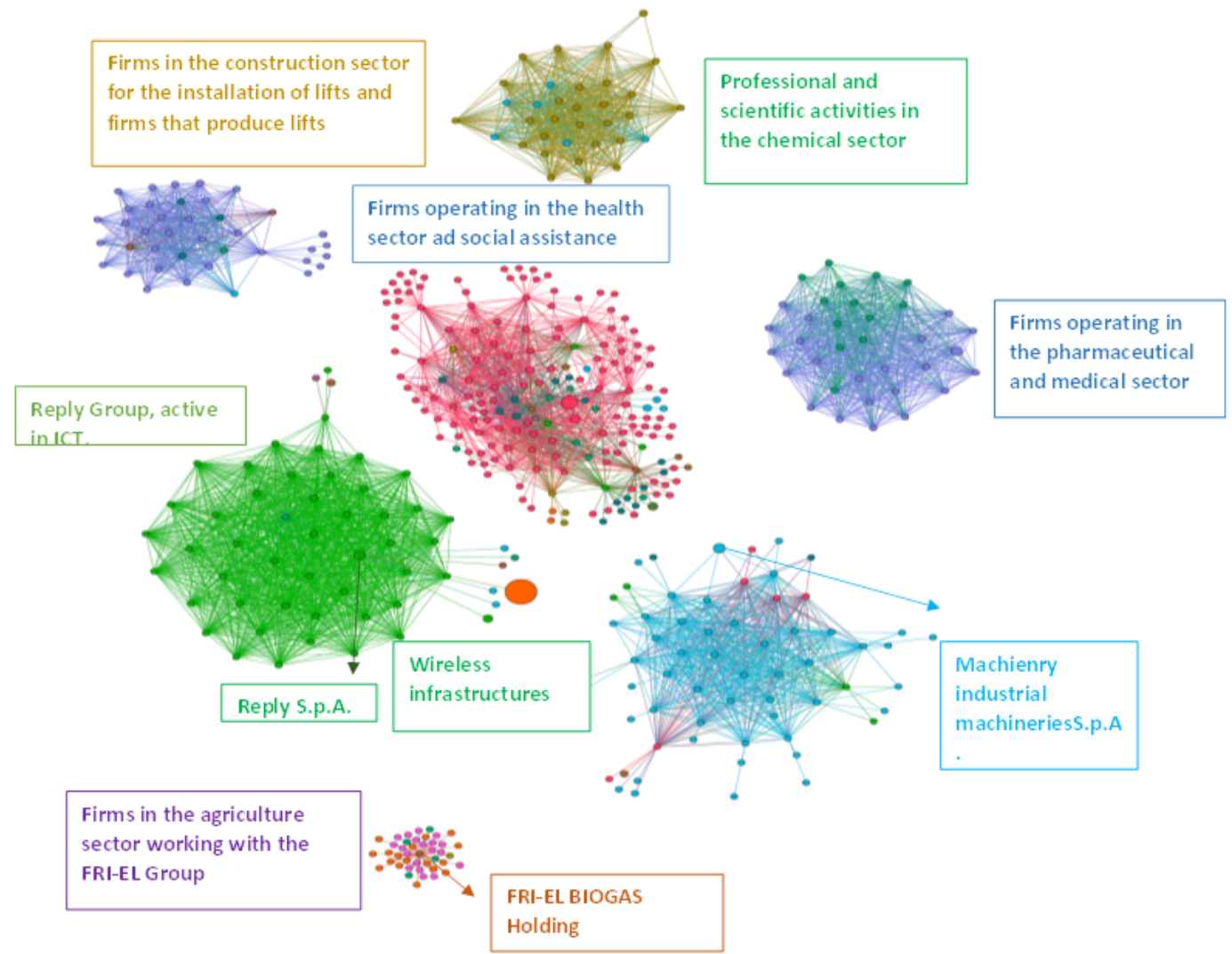




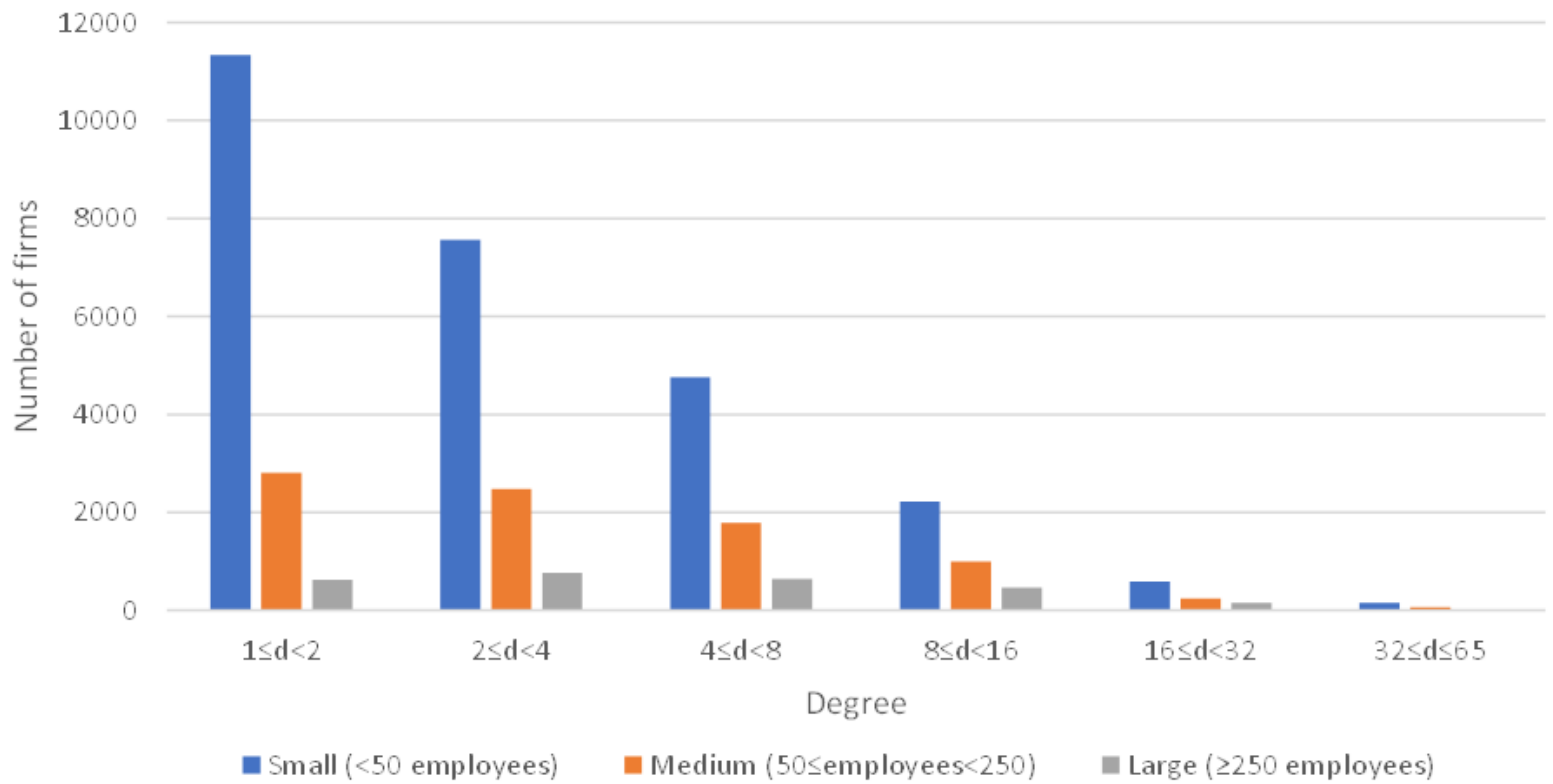

\section{Figure 4}

The distribution of firms according to degree follows a power law

Source: authors' calculations based on Aida Bureau Van Dijk.

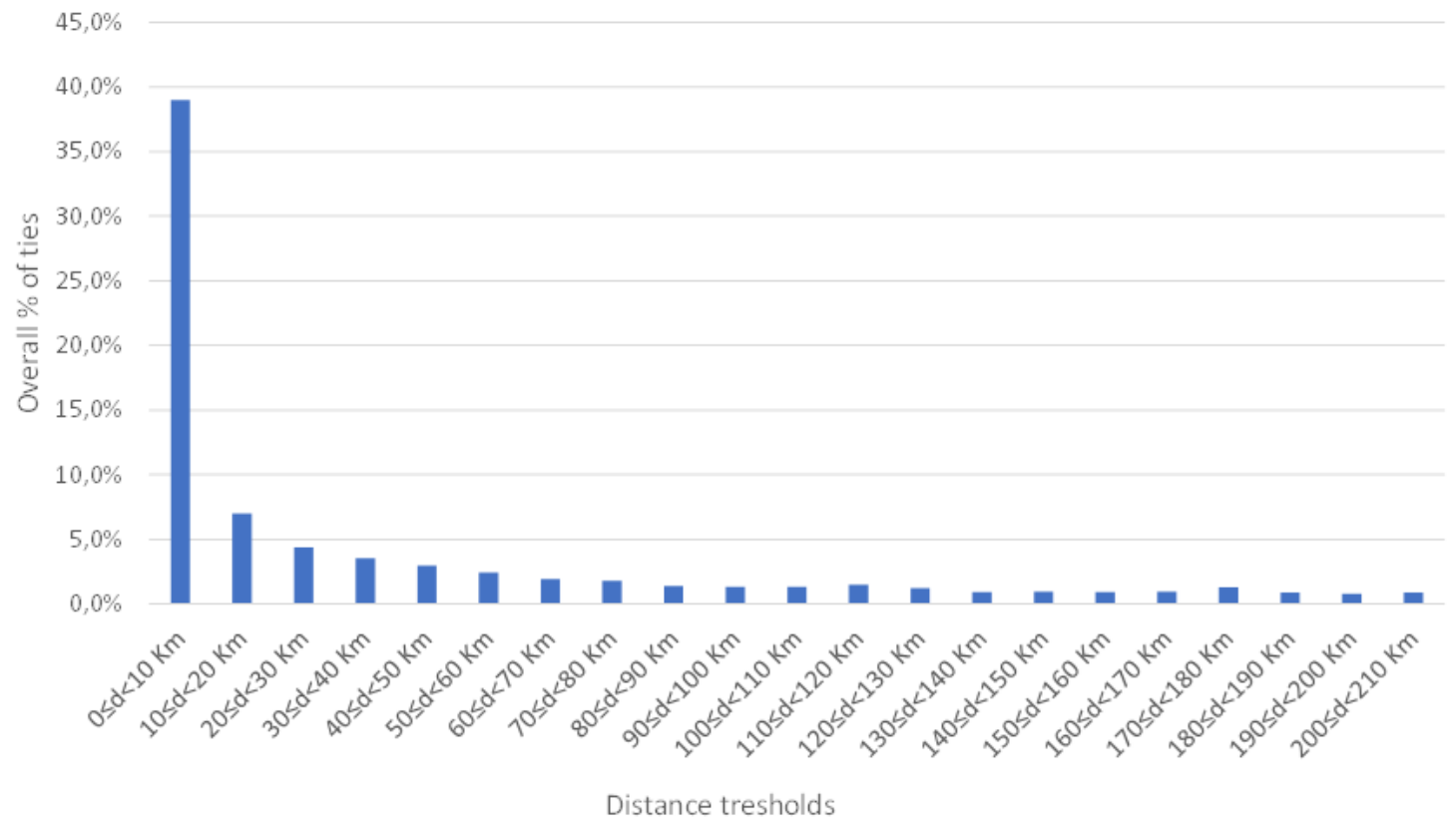

Figure 5

The distribution of ties according to distance.

Source: authors' calculations based on Aida Bureau Van Dijk.

\section{Supplementary Files}


This is a list of supplementary files associated with this preprint. Click to download.

- AppendixA.docx

Page 21/21 